\title{
Lipid Profiles Levels of Type One Diabetics Compared to Controls in Gaza Strip
}

\author{
Akram Mohammed-Refat Altaher ${ }^{*}$, Salem Sami Alewaity, Jalal Ahmed Abu-Touima \\ Medical Sciences Department, University College of Science and Technology, Gaza Strip, Palestine \\ Email address: \\ a.taher@cst.ps (A. Mohammed-Refat Altaher), Salemalewaity@gmail.com (S. S. Alewaity) \\ ${ }^{*}$ Corresponding author
}

\section{To cite this article:}

Akram Mohammed-Refat Altaher, Salem Sami Alewaity, Jalal Ahmed Abu-Touima. Lipid Profiles Levels of Type One Diabetics Compared to Controls in Gaza Strip. American Journal of Biomedical and Life Sciences. Vol. 4, No. 4, 2016, pp. 61-68.

doi: $10.11648 /$ j.ajbls.20160404.12

Received: June 24, 2016; Accepted: July 4, 2016; Published: July 21, 2016

\begin{abstract}
Background: Type 1 diabetes mellitus (T1DM) is a group of metabolic diseases characterized by hyperglycemia resulting from autoimmune destructions of $\beta$ cells lead to lack or sever reduction in insulin secretion. Coronary heart disease (CHD) is more prevalent among DM patients than other population. Higher risk of CHD is seen in DM patients who are smokers, have lipid abnormalities, obese, and hypertension. Objective: The overall aim of this study is to evaluate serum lipid profiles of patients with T1DM in comparison with age matched controls in Gaza Strip, Palestine. Materials and Methods: This study was a case control started in Jan, 2014 and finished in Sept, 2014. A total of 50 T1DM patients as a cases group and 100 age-matched healthy individuals as a controls group, aged between 3-18 years. Personal \& demographic data, and clinical data situation of the study population were taken by interview questionnaire. Anthropometric and biochemical evaluation were carried out. Collected data and biochemical analysis were analyzed using SPSS version 18. Results: There was no statistically differences among the study subjects with respect to age ( $\mathrm{P}=0.729)$. Regarding to gender, there was a statistically difference among the study subjects with respect to gender $(\mathrm{P}=0.014)$. Concerning the body mass index (BMI), the results reported that there was no statistically difference among the study subjects with respect to BMI ( $\mathrm{P}=0.146)$. Regarding lipid profiles, this research found that the percentage of high serum triglycerides (TGs) levels was significantly higher among diabetic patients than in controls $(\mathrm{p}=0.001)$, However both of them have normal TGs levels, generally. Moreover, despite of both of T1DM and controls in generally, have a normal levels of serum total cholesterol (TC), high-density lipoprotein cholesterol (HDL-C), and low-density lipoprotein cholesterol (LDL-C), there were no statistically significant differences among both of them according to these biochemical parameters ( $>>0.05$ ). On the other hand, there was no relationship between the lipid profiles in T1DM patients and the gender, family history and duration of DM, and BMI, except that, elevation of TGs levels was significantly higher in diabetic males as compared to diabetic females $(\mathrm{p}=0.011)$. Conclusions: T1DM patients group and control group were appeared with little or no progressing towards the emergence atherosclerosis and coronary risk factors; because, mostly, they were having normal serum TC, LDL-C \&, TGs with low or normal BMI.
\end{abstract}

Keywords: Diabetes Mellitus, Lipid Profiles, Coronary Heart Disease, Gaza Strip

\section{Introduction}

Diabetes mellitus (DM) is a metabolic disorder characterized by hyperglycemia with disturbances of carbohydrate, fat and protein metabolism resulting from defects in insulin secretion, insulin action, or both [1]. The two major forms of diabetes mellitus are type 1 diabetes mellitus (T1DM); resulting from autoimmune destructions of $\beta$ cells lead to lack or sever reduction in insulin secretion and type 2 diabetes mellitus (T2DM); resulting from both relative deficiency of insulin and insulin resistance [2]. T1DM and T2DM differ in their clinical presentation as well as their etiology. T1DM patients are usually younger and thinner than T2DM patients. T1DM present with acute symptoms, while T2DM develops more slowly over time. T1DM patients are more prone to develop ketoacidosis than T2DM patients [3].

The most major risk factors for diabetes mellitus are 
overweight and obesity, Most of T2DM patients were found to be obese [4]. Sedentary lifestyle, poor diet, increased late age, and family history are from the other risk factors [5]. DM may present with symptoms such as thirst, polyuria, polyphagia, polydipsia, blurring of vision, and weight loss [1]. The prevalence of DM disease in Palestine (Gaza Strip and West Bank) is about $9 \% ; 91.7 \%$ of them above of 35 years of age, whereas $8.3 \%$ of them under 35 years of age $(\mathrm{MOH}, 2011)$. DM was the Fourth $(8.6 \%)$ leading cause of death in Palestine [6].

Lipid and Lipoprotein Profiles (commonly called Lipid Profiles only) are blood test that are used to measure serum total cholesterol (TC), low-density lipoprotein cholesterol (LDL-C), high-density lipoprotein cholesterol (HDL-C) and Triglycerides (TGs) [7]. Data obtained from a Lipid Profiles can assist the physician in recommending lifestyle changes to bring the levels back in to acceptable range and thus decrease the changes heart attacks and strokes.

According to ADA, TC of $240 \mathrm{mg} / \mathrm{dl}$ or above and TGs of $500 \mathrm{mg} / \mathrm{dl}$ or above are at higher risk of heart disease. Elevation of LDL-c level (190 mg/dl or more) leads to increase risk of $\mathrm{CHD}$, stroke, and high blood pressure. Conversely, Having elevate HDL-c level $(60 \mathrm{mg} / \mathrm{dl}$ or more) does not pose a health risk, since they actually prevent some of disease caused by elevation of LDL-c level. Lipid profiles are used for diagnosis of coronary heart diseases (CHD) and other diseases [7]. Cardiovascular diseases were the main (22.4\%) leading cause of death in Palestine in 2011 [6]. Diabetes millets is the most common endocrine-metabolic disease in children [8]. Hyperlipidemia has been incriminated as a risk factor in atherosclerosis, CHD and DM [9].

Diabetic patients with hyperlipidemia frequently develop atherosclerosis which is an important cause of morbidity and mortality. Unfortunately, no study has been reported to estimate the lipid profiles levels among the different types of $\mathrm{DM}$ as compared to controls in Palestine. Therefore, this study aims to compared the lipid profiles levels among patients with T1DM and control in Gaza strip to show their predisposition to emergence atherosclerosis and CHD.

\section{Methodology}

\subsection{Study Population, Sample Size and Sampling}

The study population was comprised of 50 T1DM patients as a case group and 100 age-matched healthy individuals as a control group, aged between 3-18 years. The subjects of this study were taken from Haifa Association for Children with Diabetes in addition to Diabetology Services Unit in the Palestinian Medical Relief Society, Gaza governorate [10]. Convenience sampling techniques were used to select the study DM patients who are attending to the clinic. The sample size of the study was calculated by using the Epi-Info program version 17 at population size $=1700000,95.0 \%$ confidence interval, $2.0 \%$ confidence limit and $0.75 \%$ expected prevalence of T1DM based on previous studies that carried out in Palestine [11]. The sample size was 80 T1DM patients. Every subject in the study was given the consent form of the study. This form was included the purpose of the research, confidentiality of information, and so on. Interviewer read for each subject. In addition, All study participants was received the report of the results of their biochemical examinations after the end of the study.

\subsection{Tools of the Study}

\subsubsection{Questionnaire Interview}

A meeting interview was used for filling in a questionnaire. The questionnaire was consisted of four issues: personal data (name, age, sex, education status and so on...), clinical data (family history of diabetes, diabetes duration, type of hypoglycemic drugs and so on...), anthropometric indices (Height $(\mathrm{m})$, Weight $(\mathrm{Kg})$ and Body mass index (BMI)).

\subsubsection{Anthropometric Measurements}

The researcher was measured the body weight by using professional weighing scale (SECA type) in Kilogram, and height in centimeter by using stadiometer (SECA type), and the BMI was calculated by dividing the weight (in $\mathrm{kg}$ ) by the square of height (in $\mathrm{m}$ ). BMI is classified according to WHO classification [12].

\subsubsection{Blood Sampling, Processing and Biochemical Analysis}

About $4 \mathrm{ml}$ of fasting (14-16 hours) venous blood sample was collected from each subject in a plain tube (without anticoagulation) and samples were allowed to clot and the serum was centrifuged at room temperature by Fuhua $80-1$ centrifuge, China at $4000 \mathrm{round} /$ minute for 10 minutes. Serum was stored at $-18^{\circ} \mathrm{C}$ until analyzed. Serum was used to determine FBG, TC, TGs and HDL-C levels. FBG, TC, TG and HDL-C were measured by spectrophotomer (Stat Fax1904 Plus, USA) using ElITech clinical kit, France [13] in the clinical chemistry laboratory of University College of Science and Technology-Khanyounis, whereas LDL-C was calculated using Friedewald formula: [LDL-C $=$ TC $-(\mathrm{HDL}-$ C) $-\mathrm{TG} / 5(\mathrm{mg} / \mathrm{dl})][14]$.

\subsection{Data Analysis}

Data obtained were analyzed using Statistical Package of Social Sciences (SPSS) system (Version 18.0). Descriptive statistics (Frequencies and cross tabulation), Chi-Square test, T-Test were applied. A significant result means that the Pvalue for the hypothesis tests was less than 0.05 . The confidence intervals (CI) was reported as $95 \%$.

\section{Results}

\subsection{Personal Characteristics of the Study Groups}

The finding showed that the mean \pm standard deviation (SD) of age among the diabetic group was $11.16 \pm 4.0$ years whereas, the mean \pm SD of age was $11.55 \pm 3.6$ among control group. However, the T-Test statistical analysis showed that 
there is no statistically significant difference between the study subjects with respect to mean $\pm \mathrm{SD}$ of age in years $(\mathrm{P}=0.404)$. By using of Chi-Square Test; there were no statistically differences among the study subjects with respect to age and education level ( $\mathrm{P}=0.729 \& 0.284$ respectively) (table 1). Regarding the gender, there was a statistically difference among the study subjects with respect to gender $(\mathrm{P}=0.014)$ (table 1$)$.

Table 1. Personal characteristics of the study groups.

\begin{tabular}{|c|c|c|c|c|c|}
\hline \multirow{2}{*}{ Variables } & \multicolumn{2}{|l|}{ T1DM group } & \multicolumn{2}{|l|}{ Control group } & \multirow{2}{*}{ P-Value } \\
\hline & Frequency $(\mathrm{No} .=50)$ & Percentage (\%) & Frequency $($ No. $=100)$ & Percentage $(\%)$ & \\
\hline \multicolumn{6}{|l|}{ Age } \\
\hline 3-11 (years) & 26 & $52.0 \%$ & 49 & $49.0 \%$ & \multirow{2}{*}{0.729} \\
\hline $12-19$ (years) & 24 & $48.0 \%$ & 51 & $51.0 \%$ & \\
\hline \multicolumn{6}{|l|}{ Gender } \\
\hline Male & 27 & $54.0 \%$ & 74 & $74.0 \%$ & \multirow{2}{*}{$0.014 *$} \\
\hline Female & 23 & $46.0 \%$ & 26 & $26.0 \%$ & \\
\hline \multicolumn{6}{|c|}{ Level of education } \\
\hline Illiterate & 7 & $14.0 \%$ & 6 & $6.0 \%$ & \multirow{4}{*}{0.284} \\
\hline Primary & 17 & $34.0 \%$ & 45 & $45.0 \%$ & \\
\hline Preparatory & 17 & $34.0 \%$ & 35 & $35.0 \%$ & \\
\hline Secondary & 9 & $18.0 \%$ & 14 & $14.0 \%$ & \\
\hline
\end{tabular}

$\mathrm{P}<0.05$ : Significant, * Statistically significant, $* *$ Highly statistically significant

\subsection{Comparative Distribution of the Various Variables Among the Study Groups}

Table 2 reveals the percent comparative distribution of the BMI, FBG and lipid profiles among the study subjects. The results of the present study indicated that only $4.0 \%$ of control group was obese, whereas $50.0 \%$ of diabetic group Vs. $59.0 \%$ of control group had ideal weight $(\mathrm{p}=0.146)$ (table 2$)$.

Concerning to FBG; table 2 indicates that the majority of patients $(82.0 \%)$ in diabetic group have high FBG levels (126 $\mathrm{mg} / \mathrm{dl}$ or more) in contrast to control group in which all individuals have normal FBG levels (less than $110 \mathrm{mg} / \mathrm{dl}$ ) $(\mathrm{p}=0.192)$.

Regarding to lipid profiles in particular TC, table 2 also shows that most of the diabetic group individuals (98.0\%) Vs. most of the control group individuals (98.0\%) have normal TC levels (less than $200 \mathrm{mg} / \mathrm{dl}) \quad(\mathrm{p}=0.156)$. In addition, most of the diabetic group individuals (80.0\%) Vs. most of the control group individuals (96.0\%) have normal TG levels (less than $150 \mathrm{mg} / \mathrm{dl})(\mathrm{p}=0.001)$ (table 2).

Further to the above, Optimal LDL-C (100-129 mg/dl) and medium HDL-C (40-59 mg/dl) were found in $14.0 \% \& 2.0 \%$ respectively of the diabetic group individuals Vs. $27.0 \%$ and $1.0 \%$ respectively of the control group individuals $(\mathrm{p}=0.230$ $\& 0.615$ respectively) (table 2 ).

Moreover, according to the clinical data that was found in recording files of DM patients in Haifa Association for Children with Diabetes in addition to Palestinian Medical Relief Society, Glycated Hemoglobin (HbAlc) levels were normal $(\mathrm{HbA} 1 \mathrm{c}<6.0 \%)$ for all individuals of diabetic group.

In summary, there were no statistically significant differences among the study subjects according to BMI, TC, HDL-C, and LDL-C ( $>00.05)$. In contrast the statistically significant relation is found among the study subjects according to TGs levels $(\mathrm{p}=0.001)$ (table 2$)$.

Table 2. Comparative distribution of the various variables among the study groups.

\begin{tabular}{|c|c|c|c|c|c|}
\hline \multirow{2}{*}{ Variables } & \multicolumn{2}{|l|}{ T1DM group } & \multicolumn{2}{|l|}{ Control group } & \multirow{2}{*}{ P-Value } \\
\hline & Frequency $($ No. $=100)$ & Percentage $(\%)$ & Frequency $($ No. $=100)$ & Percentage (\%) & \\
\hline \multicolumn{6}{|c|}{ Body Mass Index } \\
\hline Underweight & 25 & $50.0 \%$ & 37 & $37.0 \%$ & \multirow{3}{*}{0.146} \\
\hline Normal weight & 25 & $50.0 \%$ & 59 & $59.0 \%$ & \\
\hline Overweight & 0 & $0.0 \%$ & 4 & $4.0 \%$ & \\
\hline \multicolumn{6}{|c|}{ Fasting blood glucose (mg/dL) } \\
\hline Less than 110 & 8 & $16.0 \%$ & 100 & $100.0 \%$ & \multirow{3}{*}{$0.000 * *$} \\
\hline $110-126$ & 1 & $2.0 \%$ & 0 & $0.0 \%$ & \\
\hline 126 or more & 41 & $82.0 \%$ & 0 & $0.0 \%$ & \\
\hline \multicolumn{6}{|c|}{ Total cholesterol (mg/dL) } \\
\hline Less than 200 & 49 & $98.0 \%$ & 98 & $98.0 \%$ & \multirow{3}{*}{0.156} \\
\hline $200-239$ & 1 & $2.0 \%$ & 2 & $2.0 \%$ & \\
\hline 240 or more & 0 & $0.0 \%$ & 0 & $0.0 \%$ & \\
\hline \multicolumn{6}{|l|}{ LDL-C (mg/dL) } \\
\hline Less than 100 & 40 & $80.0 \%$ & 65 & $65 \%$ & \multirow{4}{*}{0.230} \\
\hline $100-129$ & 7 & $14.0 \%$ & 27 & $27 \%$ & \\
\hline $130-159$ & 2 & $4.0 \%$ & 7 & $7 \%$ & \\
\hline 160 or more & 1 & $2.0 \%$ & 1 & $1 \%$ & \\
\hline
\end{tabular}




\begin{tabular}{|c|c|c|c|c|c|}
\hline \multirow{2}{*}{ Variables } & \multicolumn{2}{|l|}{ T1DM group } & \multicolumn{2}{|l|}{ Control group } & \multirow{2}{*}{ P-Value } \\
\hline & Frequency $(\mathrm{No}=100)$ & Percentage (\%) & Frequency $(\mathrm{No}=100)$ & Percentage (\%) & \\
\hline \multicolumn{6}{|c|}{ HDL-C (mg/dL) } \\
\hline Less than 40 & 49 & $89.0 \%$ & 99 & $99.0 \%$ & \multirow{3}{*}{0.615} \\
\hline $40-59$ & 1 & $2.0 \%$ & 1 & $1.0 \%$ & \\
\hline 60 or more & 0 & $0.0 \%$ & 0 & $0.0 \%$ & \\
\hline \multicolumn{6}{|c|}{ Triglycerides (mg/dL) } \\
\hline Less than 150 & 40 & $80.0 \%$ & 96 & $96.0 \%$ & \multirow{3}{*}{$0.001 *$} \\
\hline $150-199$ & 8 & $16.0 \%$ & 4 & $4.0 \%$ & \\
\hline 200 or more & 2 & $4.0 \%$ & 0 & $0.0 \%$ & \\
\hline
\end{tabular}

$\mathrm{P}<0.05$ : Significant, * Statistically significant, ** Highly statistically significant

\subsection{Relation of Lipid Profiles of T1DM Patients with Independent Variables That Suspected to Be Related}

As shown in table 3 which is illustrates the relation between lipid profiles and gender among diabetic group; there was a statistically significant relation between TG levels and gender $(\mathrm{p}=0.011)$. In contrast, there were no statistically relation between TC, LDL-C \&, HDL-C and gender among diabetic group individuals ( $>0.05$ ). Table 4 reveals the relation between lipid profiles and family history of diabetes among diabetic group individuals. thus, there were no statistically significant relation between lipid profiles and family history of diabetes among diabetic group individuals $(\mathrm{p}>0.05)$.

Table 3. Relation of lipid profiles of patients with gender.

\begin{tabular}{|c|c|c|c|c|}
\hline \multirow{2}{*}{ Variables } & \multicolumn{2}{|l|}{ Gender } & \multirow{2}{*}{ Total (\%) } & \multirow{2}{*}{ P-Value } \\
\hline & Male (\%) & Female (\%) & & \\
\hline \multicolumn{5}{|c|}{ Total cholesterol (mg/dL) } \\
\hline Less than 200 & 26 & 23 & & \multirow[b]{2}{*}{0.351} \\
\hline 200 or more & $\begin{array}{l}(52.0 \%) \\
1 \\
(2.0 \%)\end{array}$ & $\begin{array}{l}(46.0 \%) \\
0 \\
(0.0 \%)\end{array}$ & $\begin{array}{l}(98.0 \%) \\
1 \\
(2.0 \%)\end{array}$ & \\
\hline \multicolumn{5}{|c|}{ LDL-C (mg/dL) } \\
\hline Less than 100 & $\begin{array}{l}22 \\
(44.0 \%)\end{array}$ & $\begin{array}{l}18 \\
(36 \%)\end{array}$ & $\begin{array}{l}40 \\
(80.0 \%)\end{array}$ & \multirow[b]{2}{*}{0.777} \\
\hline 100 or more & $\begin{array}{l}5 \\
(10.0 \%)\end{array}$ & $\begin{array}{l}5 \\
(10.0 \%)\end{array}$ & $\begin{array}{l}10 \\
(20.0 \%)\end{array}$ & \\
\hline \multicolumn{5}{|c|}{ HDL-C (mg/dL) } \\
\hline Less than 40 & 26 & 23 & 49 & \multirow{3}{*}{0.351} \\
\hline Less than 40 & $(52.0 \%)$ & $(46.0 \%)$ & $(98.0 \%)$ & \\
\hline 40 or more & $\begin{array}{l}1 \\
(2.0 \%)\end{array}$ & $\begin{array}{l}0 \\
(0 \%)\end{array}$ & $\begin{array}{l}1 \\
(2.0 \%)\end{array}$ & \\
\hline \multicolumn{5}{|c|}{ Triglycerides (mg/dL) } \\
\hline Less than 150 & $\begin{array}{l}18 \\
(36.0 \%)\end{array}$ & $\begin{array}{l}22 \\
(44.0 \%)\end{array}$ & $\begin{array}{l}40 \\
(80.0 \%)\end{array}$ & \multirow{3}{*}{$0.011 *$} \\
\hline 150 or more & $\begin{array}{l}9 \\
(18.0 \%)\end{array}$ & $\begin{array}{l}1 \\
(2.0 \% \%)\end{array}$ & $\begin{array}{l}10 \\
(20.0 \%)\end{array}$ & \\
\hline Total (\%) & $\begin{array}{l}27 \\
(54.0 \%)\end{array}$ & $\begin{array}{l}23 \\
(46.0 \%)\end{array}$ & $\begin{array}{l}50 \\
(100.0 \%)\end{array}$ & \\
\hline
\end{tabular}

$\mathrm{P}<0.05$ : Significant, * Statistically significant, ** Highly statistically significant

Table 4. Relation of lipid profiles of patients with family history of diabetes.

\begin{tabular}{|c|c|c|c|c|}
\hline \multirow{2}{*}{ Variables } & \multicolumn{2}{|c|}{ Family history of diabetes } & \multirow{2}{*}{ Total (\%) } & \multirow{2}{*}{ P-Value } \\
\hline & Less than 2 years & 3 years or more & & \\
\hline \multicolumn{5}{|c|}{ Total cholesterol (mg/dL) } \\
\hline Less than 200 & $\begin{array}{l}43 \\
(86.0 \%)\end{array}$ & $\begin{array}{l}6 \\
(12.0 \%)\end{array}$ & $\begin{array}{l}49 \\
(98.0 \%)\end{array}$ & \multirow[b]{2}{*}{0.709} \\
\hline 200 or more & $\begin{array}{l}1 \\
(2.0 \%)\end{array}$ & $\begin{array}{l}0 \\
(0.0 \%)\end{array}$ & $\begin{array}{l}1 \\
(2.0 \%)\end{array}$ & \\
\hline \multicolumn{5}{|c|}{ LDL-C (mg/dL) } \\
\hline Less than 100 & $\begin{array}{l}34 \\
(68.0 \%)\end{array}$ & $\begin{array}{l}6 \\
(12.0 \%)\end{array}$ & $\begin{array}{l}40 \\
(80.0 \%)\end{array}$ & \multirow{2}{*}{0.192} \\
\hline 100 or more & $\begin{array}{l}10 \\
(20.0 \%)\end{array}$ & $\begin{array}{l}0 \\
(0.0 \%)\end{array}$ & $\begin{array}{l}10 \\
(20.0 \%)\end{array}$ & \\
\hline
\end{tabular}




\begin{tabular}{|c|c|c|c|c|}
\hline \multirow{2}{*}{ Variables } & \multicolumn{2}{|c|}{ Family history of diabetes } & \multirow{2}{*}{ Total (\%) } & \multirow{2}{*}{ P-Value } \\
\hline & Less than 2 years & 3 years or more & & \\
\hline \multicolumn{5}{|c|}{ HDL-C (mg/dL) } \\
\hline Less than 40 & $\begin{array}{l}43 \\
(86.0 \%)\end{array}$ & $\begin{array}{l}6 \\
(12.0 \%)\end{array}$ & $\begin{array}{l}49 \\
(98.0 \%)\end{array}$ & \multirow[b]{2}{*}{0.709} \\
\hline 40 or more & $\begin{array}{l}1 \\
(2.0 \%)\end{array}$ & $\begin{array}{l}0 \\
(0.0 \%)\end{array}$ & $\begin{array}{l}1 \\
(2.0 \%)\end{array}$ & \\
\hline \multicolumn{5}{|c|}{ Triglycerides (mg/dL) } \\
\hline Less than 150 & $\begin{array}{l}34 \\
(68.0 \%)\end{array}$ & $\begin{array}{l}6 \\
(12.0 \%)\end{array}$ & $\begin{array}{l}40 \\
(80.0 \%)\end{array}$ & \multirow{3}{*}{0.192} \\
\hline 150 or more & $\begin{array}{l}10 \\
(20.0 \%)\end{array}$ & $\begin{array}{l}0 \\
(0.0 \%)\end{array}$ & $\begin{array}{l}10 \\
(20.0 \%)\end{array}$ & \\
\hline Total (\%) & $\begin{array}{l}44 \\
(88.0 \%)\end{array}$ & $\begin{array}{l}6 \\
(12.0 \%)\end{array}$ & $\begin{array}{l}50 \\
(100.0 \%)\end{array}$ & \\
\hline
\end{tabular}

$\mathrm{P}<0.05$ : Significant, $*$ Statistically significant, ** Highly statistically significant

Table 5 demonstrates the relation between lipid profiles and duration of diabetes mellitus (in years) among diabetic group individuals. Thus, there were no statistically significant relation between lipid profiles and duration of diabetes mellitus (in years) among diabetic group individuals ( $\mathrm{p}>0.05$ ).

Table 5. Relation of lipid profiles of patients with duration of diabetes mellitus (in years).

\begin{tabular}{|c|c|c|c|c|}
\hline \multirow{2}{*}{ Variables } & \multicolumn{2}{|l|}{ DM Duration } & \multirow{2}{*}{ Total (\%) } & \multirow{2}{*}{ P-Value } \\
\hline & Less than 2 years & 3 years or more & & \\
\hline \multicolumn{5}{|c|}{ Total cholesterol (mg/dL) } \\
\hline I ces than 200 & 24 & 25 & 49 & \multirow{5}{*}{0.332} \\
\hline Less than 200 & $(48.0 \%)$ & $(50.0 \%)$ & $(98.0 \%)$ & \\
\hline 200 or more & 0 & 1 & 1 & \\
\hline 200 or more & $(0.0 \%)$ & $(2.0 \%)$ & $(2.0 \%)$ & \\
\hline \multicolumn{4}{|c|}{ LDL-C (mg/dL) } & \\
\hline Less than 100 & $\begin{array}{l}20 \\
(40.0 \%)\end{array}$ & $\begin{array}{l}20 \\
(40.0 \%)\end{array}$ & $\begin{array}{l}40 \\
(80.0 \%)\end{array}$ & \multirow{2}{*}{0.571} \\
\hline 100 or more & $\begin{array}{l}4 \\
(8.0 \%)\end{array}$ & $\begin{array}{l}6 \\
(12.0 \%)\end{array}$ & $\begin{array}{l}10 \\
(20.0 \%)\end{array}$ & \\
\hline \multicolumn{5}{|c|}{ HDL-C (mg/dL) } \\
\hline Less than 40 & $\begin{array}{l}24 \\
(48.0 \%)\end{array}$ & $\begin{array}{l}25 \\
(50.0 \%)\end{array}$ & $\begin{array}{l}49 \\
(98.0 \%)\end{array}$ & \multirow{2}{*}{0.332} \\
\hline 40 or more & $\begin{array}{l}0 \\
(0.0 \%)\end{array}$ & $\begin{array}{l}2 \\
(2.0 \%)\end{array}$ & $\begin{array}{l}1 \\
(2.0 \%)\end{array}$ & \\
\hline \multicolumn{5}{|c|}{ Triglycerides (mg/dL) } \\
\hline Less than 150 & 21 & 19 & 40 & \multirow{3}{*}{0.203} \\
\hline 150 or more & $\begin{array}{l}(42.0 \%) \\
3 \\
(6.0 \%)\end{array}$ & $\begin{array}{l}(38.0 \%) \\
7 \\
(14.0 \%)\end{array}$ & $\begin{array}{l}(80.0 \%) \\
10 \\
(20.0 \%)\end{array}$ & \\
\hline Total (\%) & $\begin{array}{l}24 \\
(48.0 \%)\end{array}$ & $\begin{array}{l}26 \\
(52.0 \%)\end{array}$ & $\begin{array}{l}50 \\
(100.0 \%)\end{array}$ & \\
\hline
\end{tabular}

$\mathrm{P}<0.05$ : Significant, ${ }^{*}$ Statistically significant, $* *$ Highly statistically significant

Table 6 describes the relation between lipid profiles and BMI among diabetic group individuals. However, there were no statistically significant relation between lipid profiles and BMI among diabetic group individuals ( $\mathrm{p}>0.05)$.

Table 6. Relation of lipid profiles of patients with BMI.

\begin{tabular}{|c|c|c|c|c|}
\hline \multirow{2}{*}{ Variables } & \multicolumn{2}{|l|}{ BMI Groped } & \multirow{2}{*}{ Total (\%) } & \multirow{2}{*}{ P-Value } \\
\hline & Underweight & Normal weight & & \\
\hline \multicolumn{5}{|c|}{ Total cholesterol (mg/dL) } \\
\hline Less than 200 & $\begin{array}{l}25 \\
(50.0 \%)\end{array}$ & $\begin{array}{l}24 \\
(48.0 \%)\end{array}$ & $\begin{array}{l}49 \\
(98.0 \%)\end{array}$ & \multirow{2}{*}{0.312} \\
\hline 200 or more & $\begin{array}{l}0 \\
(0.0 \%)\end{array}$ & $\begin{array}{l}1 \\
(2.0 \%)\end{array}$ & $\begin{array}{l}1 \\
(2.0 \%)\end{array}$ & \\
\hline \multicolumn{5}{|c|}{ LDL-C (mg/dL) } \\
\hline Less than 100 & $\begin{array}{l}19 \\
(38.0 \%)\end{array}$ & $\begin{array}{l}21 \\
(42.0 \%)\end{array}$ & $\begin{array}{l}40 \\
(80.0 \%)\end{array}$ & \multirow{2}{*}{0.480} \\
\hline 100 or more & $\begin{array}{l}6 \\
(12.0 \%)\end{array}$ & $\begin{array}{l}4 \\
(8.0 \%)\end{array}$ & $\begin{array}{l}10 \\
(20.0 \%)\end{array}$ & \\
\hline
\end{tabular}




\begin{tabular}{lllll}
\hline Variables & BMI Groped & Total (\%) & P-Value \\
\cline { 2 - 3 } HDL-C $(\mathrm{mg} / \mathrm{dL})$ & Underweight & 25 & 49 \\
Less than 40 & 24 & $(50.0 \%)$ & $(98.0 \%)$ & 1 \\
& $(48.0 \%)$ & 0 & $(2.0 \%)$ \\
40 or more & 1 & $(0.0 \%)$ & 40 \\
Triglycerides (mg/dL) & $(20.0 \%)$ & 19 & $(80.0 \%)$ \\
Less than 150 & 21 & $(38.0 \%)$ & 10 & $\mathbf{0 . 3 1 2}$ \\
& $(42.0 \%)$ & 6 & $(20.0 \%)$ \\
150 or more & 4 & $(12.0 \%)$ & $\mathbf{5 0}$ \\
Total $(\%)$ & $(8.0 \%)$ & 25 & $(\mathbf{1 0 0 . 0} \%)$ \\
\hline
\end{tabular}

$\mathrm{P}<0.05$ : Significant, $*$ Statistically significant, ${ }^{* *}$ Highly statistically significant

\section{Discussion}

There are some factors involved in increasing the risk of CHD like DM, hypertension, smoking, physical inactivity (sedentary PA), obesity and, serum lipid profiles levels. CHD risk factors modification like reduction of blood pressure, blood cholesterol level, and cigarette smoking decreases the incidence of death associated with it [15]. Therefore, the present work is the first to evaluate serum lipid profiles and other CHD risk factors of patients with T1DM in comparison with controls in Gaza Strip to show their predisposition to emergence CHD. Patients with Diabetes mellitus can have many lipid abnormalities, including elevated levels of total serum cholesterol, serum TGs, LDL-C, VLDL-C and low level of HDL-C especially if the blood sugar uncontrolled. These patients have a preponderance of abnormalities in the composition of LDL-C, which increase atherogenicity even if the absolute concentration of LDL-C is not significantly increased. The combination of elevated levels of LDL-C particles and high triglyceride levels represents a lethal cholesterol abnormality [16].

\subsection{Personal Characteristics of the Study Groups}

In the present study $26(52.0 \%)$ of the patients were $3-11$ years of age whereas $24(48.0 \%)$ of them were in between 12-19 years of age, this could be explained that generally, the incidence of T1DM is age-dependent with a range of fewer than 1 per 1000 at age 5 years to approximately 3 per 1000 at age 16 years, Incidence increases with age and peaks in early to middle puberty [17]. but T1DM can occur at any age [18]. Regarding to gender, the results of the present findings found that $27(54.0 \%)$ of patients were males and $23(46.0 \%)$ were females; this could be explained that male and female subjects are approximately affected [17]. Concerning the BMI, the results of the current study reported that half of patients $(50.0 \%)$ were underweight and the other half were normal weight in comparison with the results of the control where $37(37.0 \%)$ were underweight, 59 (59.0\%) were normal weight, and $4(4.0 \%)$ were overweight. although this difference was not statistically significant $(\mathrm{P}=0.146)$. Weight loss could be due to insulin deficiency which cause breakdown of protein and fat [18].

\subsection{Lipid Profiles Among the Study Subjects}

In this study we found that the percentage of high serum TGs was significantly higher among diabetic patients than in controls $(p=0.001)$, although both of them have normal TGs levels generally (less than $150 \mathrm{mg} / \mathrm{dl}$ ). This is concordance with other studies conducted elsewhere and reported a statistically elevated for TGs levels among T1DM patients as compared to control like Khalil et al. (2006) in Amman-Jordan [16], Al-Naama et al. (2002) in Basrah-Iraq [19], and Erciyas et al. (2004) in AmsterdamNetherlands [20]. Regarding to TC, the present study also shows that most of the diabetic group individuals (98.0\%) Vs. most of the control group individuals (98.0\%) have normal TC levels $(\mathrm{p}=0.156)$. Further to the above, Optimal LDL-C and medium HDL-C were found in $14.0 \%$ \& $2.0 \%$ respectively of the diabetic group individuals Vs. $27.0 \%$ and $1.0 \%$ respectively of the control group individuals ( $p=0.230 \& 0.615$ respectively). A summary of the above, there were no statistically significant differences among T1DM patients as compared to controls according to the TC, HDL-C, and LDL-C levels $(p>0.05)$. However, this results was not in agreement with the other studies which reported a significant elevated in serum TC, LDL-C and VLDL-C ratio among T1DM patients comparing to controls $[19,20]$.

But in contrast to the above, Imani et al. in Isfahan-Iran reported a significant decrease in serum TC, LDL-C in diabetic patients as compared to control, and this difference could be due to tight nutritional control in diabetic group -as the authors attributed in the study- [21]. The results of our study are not in agreement with the belief that the level of the HDL-C is normal or increased in type 1 DM [22].

\subsection{Relation of Lipid Profiles of T1DM Patients with Independent Variables That Suspected to Be Related}

Regarding the relation between lipid profiles and gender among diabetic group individuals; the present finding showed there was a statistically significant relation between TG levels and gender $(\mathrm{p}=0.011)$. In contrast, there were no statistically relation between serum TC, LDL-C \&, HDL-C and gender $(p>0.05)$. This is in concordance with the 
finding of Patiakas et al. (2007) in Greece study who found that there was no statistically significant relation between male and female of T1DM according to levels of serum TC and LDL-C [22]. But in contrast to the results reported by Perez et al in Barcelona-Spain who showed that female with type 1 diabetes displayed higher concentrations of LDL-C and a higher prevalence of hypercholesterolemia when glycemic control was poor, and the results were statistically significant [23]. This difference of results could be due to the difference in the sample size and age group between both studies.

Concerning the relation between lipid profiles and family history of diabetes among diabetic group individuals; the present study observed that there were no statistically significant relation between lipid profiles and family history of diabetes among diabetic group individuals ( $p>0.05$ ), and it is important to mention that no further studies have been found between the family history and lipid disorders.

About of, the relation between lipid profiles and duration of diabetes mellitus (in years) among diabetic group individuals; the finding of the present study showed that there were no statistically significant association between lipid profiles and duration of diabetes mellitus (in years) among diabetic group individuals $(p>0.05)$, and it is important to mention that no further studies have been found between the duration of diabetes mellitus (in years) and lipid disorders.

Concerning of the relationship between lipid profiles and BMI among diabetic group individuals. The present study reported that there were no statistically significant relation between lipid profiles and BMI among diabetic group individuals $(p>0.05)$. These results were in concordance with the reports of Bianga et al. (2006) in Japanese study [24] and Herbert et al. (2000) in Philippine study [25].

\section{Conclusions}

- T1DM patients group was higher in the percentage of high serum TGs levels than controls group, and this difference was reached a statistically difference level $(p=0.001)$. Although, generally, both of them had normal TG levels.

- There were no statistically significant differences among the study subjects according to BMI in addition to serum TC, HDL-C, and LDL-C levels ( $p>0.05)$ although, generally, all of them have normal TGs levels.

- There was no relationship between the lipid profiles in T1DM patients and the gender, family history of DM, duration of DM and BMI, except that, elevation of TGs levels was significantly higher in diabetic males as compared to diabetic females $(\mathrm{p}=0.011)$.

- T1DM patients group and control group were appeared with little or no progressing towards the emergence atherosclerosis and coronary risk factors; because, mostly, they were having normal of serum TC, LDL-C, TGs and BMI.

\section{Recommendations}

T1DM patients should be kept on regular check-up for early detection of coronary risk factors (epically lipid abnormalities) which in turn reduce the risk of $\mathrm{CHD}$ and diabetes complications. In addition, blood glucose control and dietary guidelines should be improved among T1DM patients. Moreover, further studies with large sample size is highly recommended to authenticate the findings from this study.

\section{References}

[1] A. Wendy, B. Jean, "Clinical Chemistry Text Book". 1st ed., F. A. Davis Company. USA. pp 147-155, 2007.

[2] P. Cohen, "The 20th century struggle to decipher insulin signaling”, Nat Rev Mol Cell Biol., 7, pp 867-873, 2006.

[3] A. Altaher, "The Effect of Ramadan Fasting on Biochemical Parameters among Type 2 Diabetic Patients in Gaza Governorate". Master theses, IUG Journal of Natural and Engineering Studies, 21 (1), pp 485-518, 2013.

[4] M. Yassin, H. Altibi, and A. El Shanti, "Biochemical Features of Type 2 Diabetic Patients in Gaza Governorate ", Submitted to the West African Journal of Medicine, 14, pp 580-585, 2009.

[5] M. Fujita, K. Ueno, and A. Hata, "Effect of obesity on incidence of type 2 diabetes declines with age among Japanese women", Experimental Biology and Medicine, 234, pp 750-757, 2009.

[6] Ministry of Health, Palestine Health Information Center, Non Communicable disease. Health Status in Palestine, 2011 (Accessed 25-3-2014).

[7] American Diabetes Association, Standards of Medical Care in Diabetes. Diabetes Care. 30, pp 4-41, 2013 (Accessed 2-3- 2014).

[8] A. A. Alrabaty, A. A. Alnakshabandi, N. B. Yahya, "The Lipid Profile in Children with Type 1 Diabetes Mellitus in Erbil Governorate", THE IRAQI POSTGRADUATE MEDICAL JOURNAL, 8 (4), 2009.

[9] A. J. Krentz, "Lipoprotein abnormalities and their consequences for patients with type 2 diabetes" Diabetes Obes Metab., 5 (1), pp 19-27, 2003.

[10] Palestinian Medical Relief Society (PMRS) "About Palestinian Medical Relief Society", 2013. http://www.pmrs.ps (Accessed 2-5- 2014).

[11] Ministry of Health (MOH) "Palestinian Clinical Laboratory Tests Guide". Palestinian Health Information Center, Palestine, 2005. (Accessed 20-4- 2014).

[12] World Health Organization, "Obesity and overweight", Fact sheet number 311. Geneva, 2012. http://www.who.int/mediacentre/factsheets/fs311/en/index.ht $\mathrm{ml}$ (accessed 10-4-2014).

[13] M. H. Burstein, R. Scholnick, and R. Morfin, " Rapid Method for Isolation of Lipoproteins from Human Serum by Precipitation with Polyanion", Journal of Lipid Research, 11, 583, 1970.

[14] W. T. Friedewald, R. I. Levy, and D. S. Fredrickson, "Estimation of the concentration of low-density lipoprotein cholesterol in plasma without use of the preparative ultracentrifuge", Clinical Chemistry Journal, 18 (6) pp 499$502,1972$. 
[15] M. M. Engler, M. B. Engler, D. M. Daridson and R. E. Slaughter "Cardiovascular disease prevention, knowledge and attitudes of graduate nursing students", Journal of Advanced Nursing, 17: pp 1220-1225, 1992.

[16] N. Khalil "Clinical study of lipid profile in diabetic patients", Middle East Journal of Family Medicine, 4 (5), 2006.

[17] L. P. Oski's, "Pediatrics principles and pediatrics", 4th ed., Philadiliphia, saunders, 2006.

[18] H. William, "Diabetes Mellitus, Type 1". [Online] 2014. Available at www. emedicine.com/ped/topic581.htm (accessed 10-4-2014).

[19] L. M. Naama, M. Kadhim, M. S. Aboud "Lipid profile in children with insulin dependent diabetes mellitus", J Pak Med Assoc., 52, pp 29-34, 2002.

[20] F. Erciyas, T. Fatma, A. Bana, U. Yasemin, "Glycemic control, oxidative stress and lipid profile in children with type 1 diabetes mellitus", Arch Med Res, 35, pp 134-140, 2004.

[21] S. F. Imani, M. Hashmipour, R. Kelishadi, "Lipid profilre of children with type 1 diabetes compared to controls", ARYA Journal, 2, pp 36-38, 2006.

[22] S. Patiakas, N. Kiriakopoulos, C. Gavala, I. Aggos, K. Akritopoulou, P. Akritopoulos, et al. "The lipid profile of patients with diabetes mellitus in Paionia country", Diabetologie und Stoffweechsel, 10, 1055, 2007.

[23] P. Antonio, M. Ana, C. Gemma, G. Gabriel, L. Jose, R. Mercedes, et al. "Prevalence and Phenotypic Distribution of Dyslipidemia in Type 1 Diabetes Mellitus", Arch Intern Med., 160, pp 2756-2762, 2000.

[24] M. Bianga, G. Deja, C. Jarosz, T. Malecka, M. Kalina, M. Grychtol, "Evaluation of selected risk factors of atherosclerosis in children with type 1 hypercholesterolemia", Endocrynol Diabetol Chor Przemiany Wieku Rozw, 12, pp 25-30, 2006.

[25] Ho. Herbert, G. Partica, A. Mary, M. D. Batongbacal, "The lipid profile of Diabetic Patients at the Diabetes Clinic of the Philippine general hospital", Philipp J Intern Med, 38, pp 1620, 2000. 